\title{
Exploring Typology of Residents Staying in Disaster-Prone Areas: A Case Study in Tambak Lorok, Semarang, Indonesia
}

\author{
Choirul Amin ${ }^{1,2,}$, Sukamdi $^{3}$, Rijanta ${ }^{3}$ \\ ${ }^{1}$ Faculty of Geography, University of Muhammadiyah Surakarta, Jl. A. Yani Tromol Pos 1, \\ Surakarta 57162, Indonesia \\ ${ }^{2}$ Doctoral Program, Faculty of Geography, University of Gadjah Mada, Jl. Kaliurang, Bulaksumur, \\ Yogyakarta 55281, Indonesia \\ ${ }^{3}$ Faculty of Geography, University of Gadjah Mada, Jl. Kaliurang, Bulaksumur, Yogyakarta 55281, \\ Indonesia \\ *) Corresponding author (e-mail: ca122@ums.ac.id)
}

\begin{abstract}
The understanding of the typology of residents living in disaster-prone areas is important as inputs for policy-makers, especially regarding the relocation of people from disaster-prone areas to be effective. However, studies on population immobility, especially in relation to climate change-related disaster, are limited. As a consequence, the phenomenon of population immobility in disaster-prone areas is unclearly explained. This study contributes in explaining population immobility by exploring the typology of residents who reluctant to move from disaster-prone areas. We use a case study of Kampung Tambak Lorok Semarang, which is prone to three disasters simultaneously, i.e. sea level rise, land subsidence, and tidal inundation. This study is a survey research in which the samples were selected using area sampling strategy. Data was collected using questionnaire surveys of 235 heads of households recording two main variables (1) demographic, social, and economic characteristics of people who did not move from disaster-prone areas; and (2) staying intention in disaster-prone areas. Data was analysed by descriptive statistics using table and graph to describe the respondent characteristic and the relation with the intention to stay. We identified that there are three types of residents which are described based on its sociodemographic characters including (1) Type-1, residents who strongly decide to stay (positive response); Type-2, residents who have no decision whether to move or stay (neutral response); and (3) Type-3, residents who have yet decided to move (negative response). The results of this study provide empirical evidence to the migration theory debate at the micro level. Specifically, the intention to stay is a key element in the "black box' of immobile decision-making from disaster-prone areas.
\end{abstract}

Keywords: migration, immobility, staying intention, climate change, tidal inundation, land subsidence, Tambak Lorok.

\begin{abstract}
Abstrak. Pemahaman atas tipologi penduduk yang bertahan tinggal di daerah rawan bencana ini penting untuk masukan bagi penentu kebijakan, khususnya terkait kebijakan relokasi penduduk dari daerah rawan bencana agar dapat berjalan efektif. Namun demikian, studi tentang immobilitas penduduk terutama immobilitas yang dikaitkan dengan bencana perubahan iklim masih sangat sedikit sehingga penjelasan tentang immobilitas penduduk di daerah rawan bencana masih kabur. Penelitian ini mengeksplorasi tipologi penduduk yang tidak pindah dari daerah rawan bencana untuk memberi sumbangan penjelasan tentang immobilitas penduduk. Survey dilakukan kepada penduduk Kampung Tambak Lorok Semarang yang merupakan daerah rawan terhadap 3 bencana sekaligus yakni kenaikan muka air laut, penurunan tanah, dan genang pasang. Sampel penelitian sebanyak 235 Kepala Keluarga yang dipilih menggunakan teknik proporsional area sampling. Data dikumpulkan menggunakan kuesioner yang terdiri atas 2 bagian: (1) karakteristik demografi, sosial, dan ekonomi responden; dan (2) keinginan tinggal di daerah rawan bencana. Analisis data menggunakan analisis deskriptif dengan menggunakan
\end{abstract}


tabel frekuensi dan grafik tentang karakteristik responden dan kaitan antara karakteristik responden dan staying intention di daerah penelitian. Tiga (3) tipologi telah teridentifikasi, yaitu: Tipe-1 penduduk yang ingin tetap tinggal; Tipe-2 penduduk yang masih belum memutuskan apakah akan tetap tinggal atau pindah; dan Tipe-3 penduduk yang tidak ingin tinggal. Masing-masing tipologi tersebut dideskripsikan berdasarkan tempat lahir, umur, lama tinggal, pendidikan, pekerjaan, dan penghasilan. Hasil penelitian ini juga menyumbangkan bukti empiris pada debat teori migrasi di tingkat mikro, yakni bahwa keinginan tinggal merupakan elemen kunci di dalam 'kotak hitam' pembuatan keputusan tinggal dari daerah rawan bencana.

Kata Kunci: Migrasi, imobilitas, keinginan tinggal, perubahan iklim, genang pasang, penurunan tanah, Tambak Lorok.

\section{Introduction}

The perspective on human migration following natural hazard has two inseparable sides, namely migration (moving) and immobility (not moving) (King, 2012). King (2012) argues that one of the future challenges for migration theorization is the importance of explanation regarding people who do not migrate (immobile). There are significant challenges emerging globally in relation to both the future of human mobility and the broader impacts of disaster due to climate change (Bardsley \& Hugo, 2010). The interaction between these two processes is little understood and significantly underresearched. Although the scale of the impact of environmental disasters to people is massive, but there is inadequate study on the mechanism on how this drives to migration phenomenon (Hugo, 2008).

The decision of people in disaster-prone areas whether to stay or to move in responding the potential disaster is influenced by various aspects. From an individual perspective, there are push and pull factors that influence their intension (Lee, 1996). Theoretically, people with high push factors will migrate to cope with the conditions. However, in some cases there are individuals who do not migrate when there is an adequate push and pull factor from their environment. One example is in the case of the coastal area of Semarang city, where the people living in this area are experienced with sea level rise, land subsidence, and tidal inundation $(r o b)$ in the same time (Arief et al., 2012; Marfai et al., 2008). Although 93\% of people are aware that their area subject to those disaster impact, but they keep living in this area. Even, when the tidal water is gradually getting higher.

Viewing from Lee's (1996) perspective of migration model, people in that area have strong push factors to migrate due to hazard, but failed to motivate them leaving the area. Studies on human migration due to disasters exists (e.g., De Groot et.al., 2011; De Jong et al., 1996; Lu, 1998; Massey, 1999). Nevertheless, the study of population immobility, especially the immobility associated with climate changerelated disasters, is still very limited. Hence, this phenomenon is unclearly explained. Therefore, this study aims to explain this phenomenon by exploring the typology of residents who immobile from disaster-prone areas. We choose a case of Semarang city coast area as there is an interesting phenomenon to examine in relation to disaster-driven migration.

The coastal area of Semarang city is prone to various environmental problems such as tidal inundation, land subsidence, and flood during the rainy season (Suhelmi et al., 2014). Most of the coastal areas of Semarang (20 urban villages) have high levels of hazard-risk and vulnerability to tidal inundation (Arief et al., 2012). The causes of tidal inundation are sea level rise due to climate change and land subsidence (Marfai et al., 2008; Marfai \& King, 2008). The impact of tidal inundation is estimated to be higher with the assumption of sea level rise and land subsidence are constantly increasing up to $15 \mathrm{~cm} /$ year (Abidin et al., 2010). This condition brings Semarang coastal area becomes unsafe and uncomfortable due to frequent flooding. 
Table 1. Proportion of samples at each RW in Tambak Lorok.

\begin{tabular}{lcc}
\hline \multicolumn{1}{c}{ Area } & Number of heads of households & Number of samples (N) \\
\hline RW XII & 337 & 54 \\
RW XIII & 235 & 38 \\
RW XIV & 363 & 58 \\
RW XV & 368 & 59 \\
RW XVI & 165 & 26 \\
\hline Total & 1,468 & 235 \\
\hline
\end{tabular}

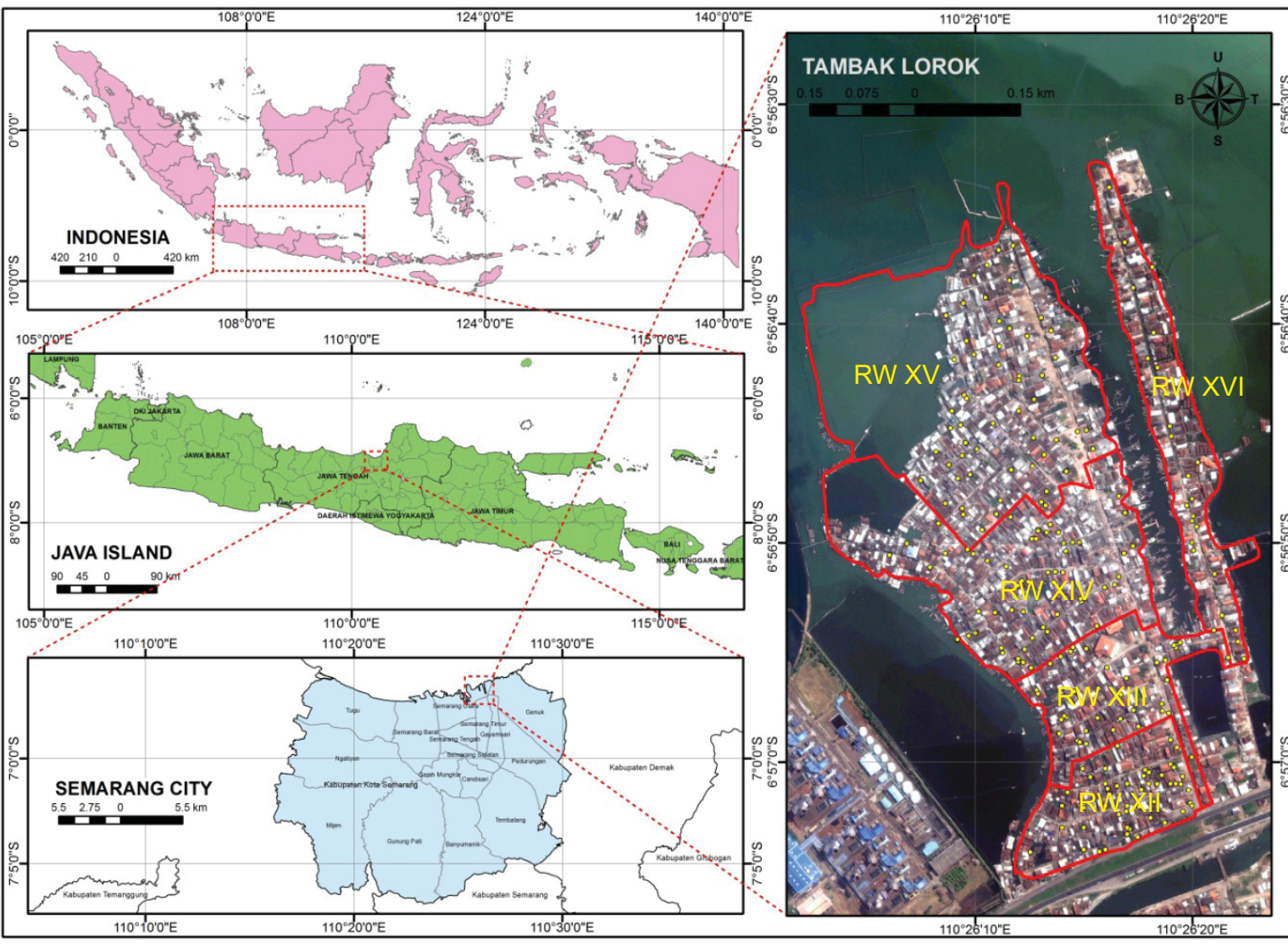

Figure 1. Research location.

We used Kampung Tambak Lorok as a case study since this area is frequently facing severe tidal inundation events (Arief et al., 2012). This is an interesting area for the case study because of various aspects. It is located not only in the coastal area of Semarang, but also close to urban areas. Where the livelihoods of people, which are densely living, depend on marine resources. Moreover, the environment of this area is unhealthy and severely affected by periodic tidal inundation that are exacerbated by sea level rise and land subsidence. Considering such high level of migration push factors, in theory, the people should leave their area because the area is economically disadvantage, physically dangerous, and socially unfavourable. However, in reality, people in the area do not move elsewhere.

This study focuses on staying intention that allows to provide information about the potential of living in disaster-prone areas. The detail information of this area and the method on collecting data is provided in Section 2 followed by the results and discussion of the typology (Section 3). Lastly, the major finding of this study is concluded in Section 4. 


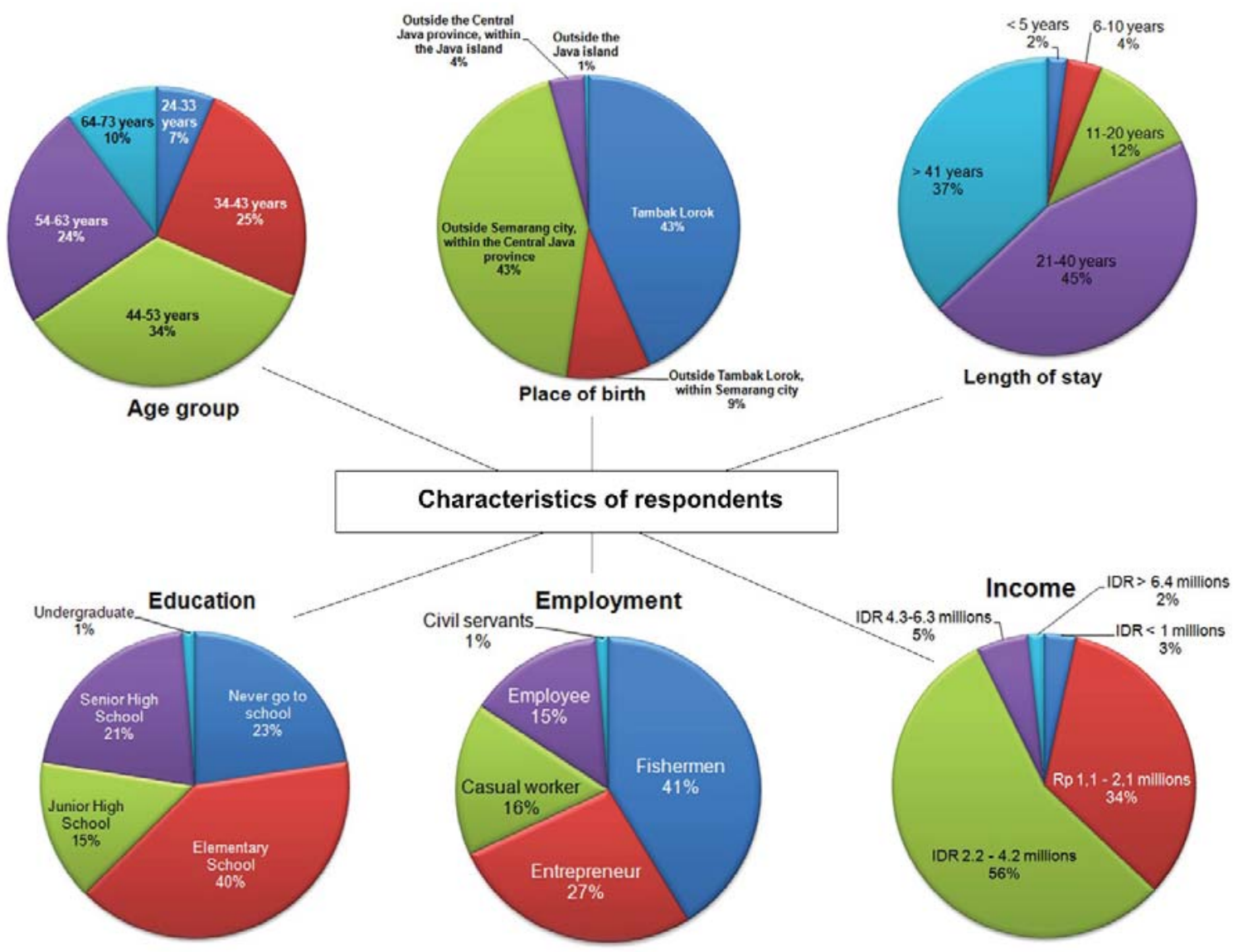

Figure 2. Characteristics of respondents.

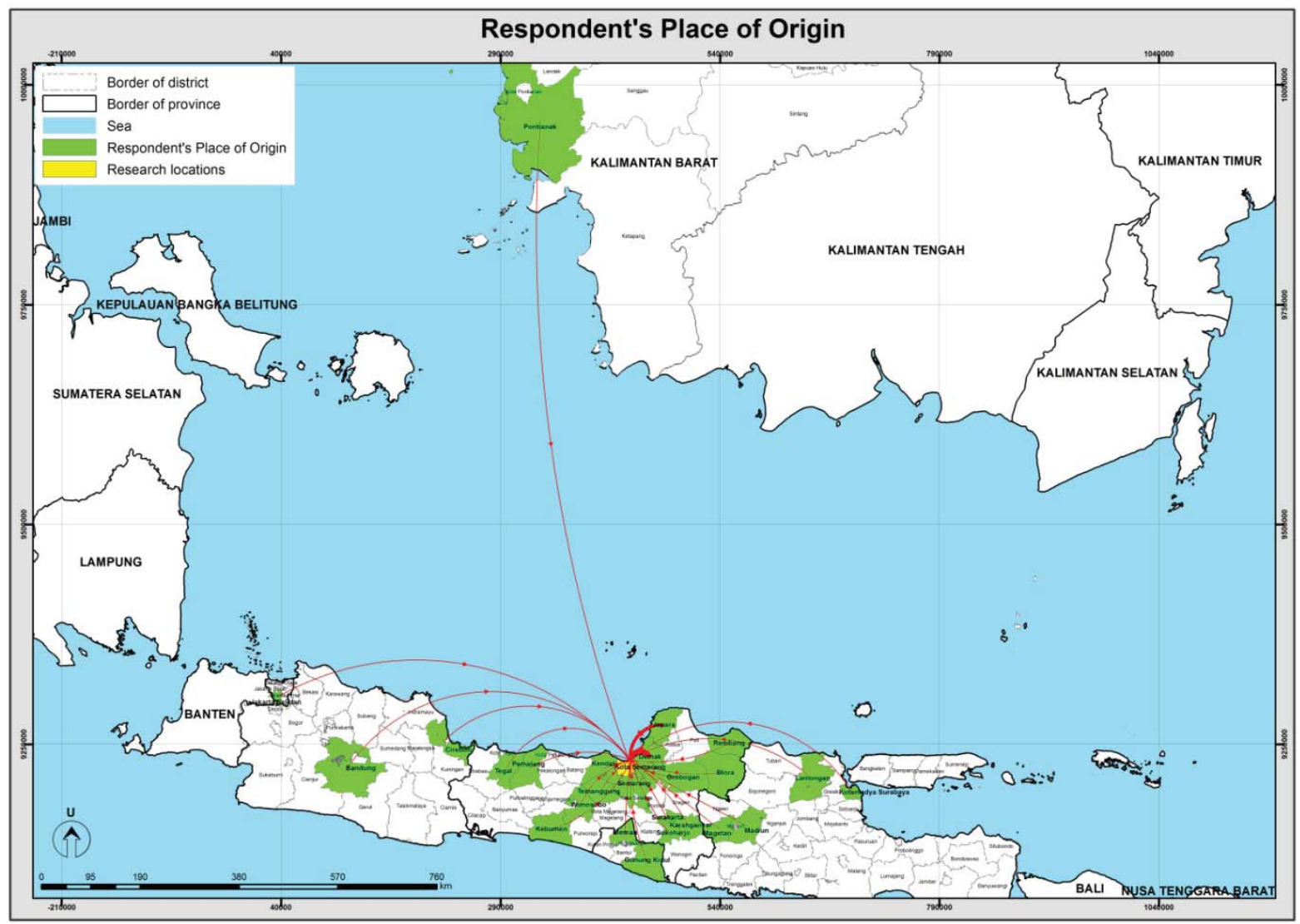

Figure 3. Respondent's Place of Origin. 


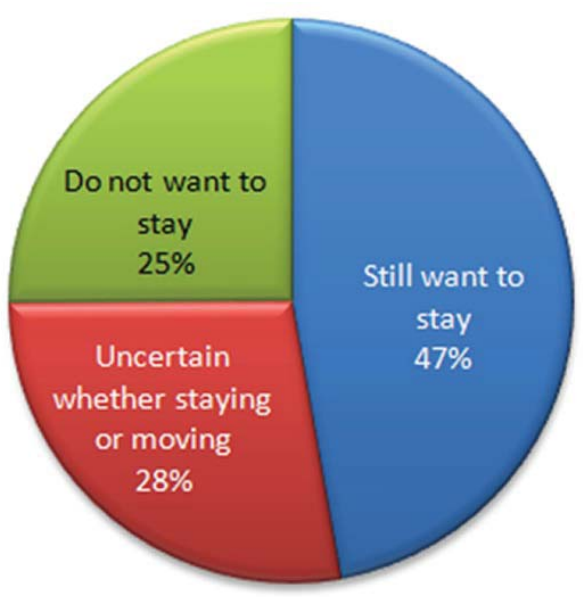

Figure 4. Staying intention in Tambak Lorok.

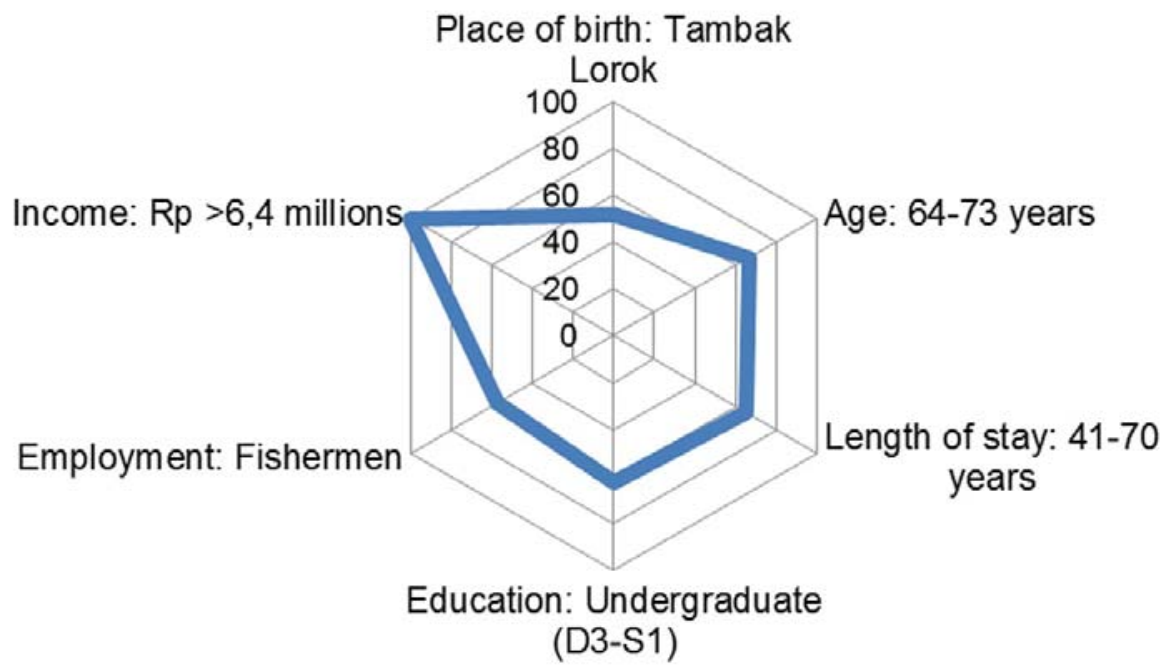

Figure 5. Characteristics of Residents who still want to stay.

\section{Research Method}

\subsection{Study Area}

This study explored the intention to stay in disaster-prone area using a case study by survey method. The surveys involved people living in disaster-prone areas of Semarang coast that are frequently affected by severe tidal inundation. This area was selected as a case study as the research location based on three considerations including (1) the most severe areas affected by tidal inundation (has highest physical push factor); (2) the most populous area (has highest social push factor); and (3) the area with the greatest number of poor people (has highest economic push factor). Kampung Tambak Lorok is part of Kelurahan Tanjung Mas, North Semarang Sub district, Semarang City, Central Java Province, Indonesia. The total area of this kampong is about $31 \mathrm{Ha}$ which is divided into 5 Rukun Warga (RW), i.e. RW XII, XIII, XIV, XV, and XVI. This is located on the northernmost part of Kelurahan Tanjung Mas and in direct contact with the Java Sea (see Figure 1).

\subsection{Data Collection and Analysis}

The research participants were residents of Kampung Tambak Lorok which were selected from the total of 1,468 heads of households (Monograph of Kelurahan Tanjung Mas, 2016). The sample size was 235 heads of households. This was calculated using Slovin formula (Ryan, 2013) with 95\% significance level. Samples were selected using area sampling technique, where the sample selection based on area of Rukun Warga (RW) in Kampung Tambak Lorok. Kampung Tambak Lorok consists of 4 
RWs (i.e. RW XII, XIII, XIV, XV and XVI) with the proportion of the sample in each RW is $16 \%$ of the total number of households in each RW (Table 1).

The data were collected using questionnaires and analysed by descriptive statistics. Questionnaires were arranged according to conceptual framework of research, which further developed in the form of question items based on the purpose of this research. Questions in the questionnaire consisted of two parts: (1) the demographic, social, and economic characteristics of respondents; and (2) respondents staying intention. This research asked respondents: "How is your staying intention in Tambak Lorok?" with answers choices: (1) still want to stay; (2) uncertain between want to stay or move; and (3) do not want to stay. By descriptive statistics, the data arranged into frequency tables and displayed in graphical. The descriptive analysis uses tables and graphs by linking the characteristics of respondents with their staying intention in Tambak Lorok.

\section{Results and Discussion}

\subsection{Characteristics of Residents Living in Disaster-prone Areas}

Characteristics of respondents i.e. residents who immobile from tidal inundation-affected areas in coastal Semarang described by age, place of birth, length of stay, education level, type of work, and income. These characteristics are summarized and displayed in Figure 2. Respondents are mostly in the productive age between 24 to 63 years old $(90 \%)$, while those who are unproductive (aged over 64 years) are only a small part $(10 \%)$. Meanwhile, the respondents' place of birth showed their area of origin (see Figure 3). The respondents who are natives of Kampung Tambak Lorok (born in Tambak Lorok) were $43.4 \%$, while the respondents who were born outside Tambak Lorok were $56.6 \%$ of the respondents. This indicated that more than half of all respondents are immigrants from outside the research area. That is, they were born outside Kampung Tambak Lorok and then moved to Kampung Tambak Lorok.
The participants were varying in their socio-demographic characteristics. Most of the respondents have been living in Tambak Lorok between 21-40 years (45.1\%) and over 41 years (37\%). This showed that most respondents have been living in Tambak Lorok for a relatively long period of time (more than 21 year). The time someone spent living in the same place (in this case, for more than 21 years) is more than enough time to understand the physical, social, and economic conditions of Tambak Lorok. They have experienced difficulties and happiness in Tambak Lorok for a long time. The education level of respondents is dominated by elementary school (40\%). There are even respondents who have never attended school $(22.6 \%)$. There are only a few of the respondents who graduated from junior high school (14.9\%) and senior high school (21.3\%). While the respondents that graduated from university (D3 and S1) are small part (1.3\%) of respondent. In general this indicates that the education level of respondents is low. Based on their occupation, most respondents $(41.3 \%)$ work as fishermen. Respondents who work as entrepreneurs $(26.8 \%)$ are entrepreneurs in the field of fish processing. Respondents are residents who live in the coastal area which is the largest fishing village in Semarang city, so it is reasonable if most of their livelihood is related to the sea, such as fishermen, fish processing, and fish traders. Respondents who worked as casual labourers $(16.2 \%)$ worked erratically (often changed). They sometimes become masons and porters at the Port of Tanjung Emas. While respondents who work as contract employees $(14.5 \%)$ are employees for factories in Tanjung Emas Port industrial area. The fewest respondents are those who work as permanent employees (1.3\%), which are teachers and employees of Semarang City Government. In terms of income, most respondents (56\%) earn between IDR 2.200.000 - IDR 4.200.000. The city's minimum wage (UMK) of Semarang in 2016 is IDR 2,125,000 which is the highest wage rate in Central Java Province. Thus, most of the respondents have income above the UMK of Semarang 2016. This showed that they have enough income to meet the minimum cost of living in Semarang city. 


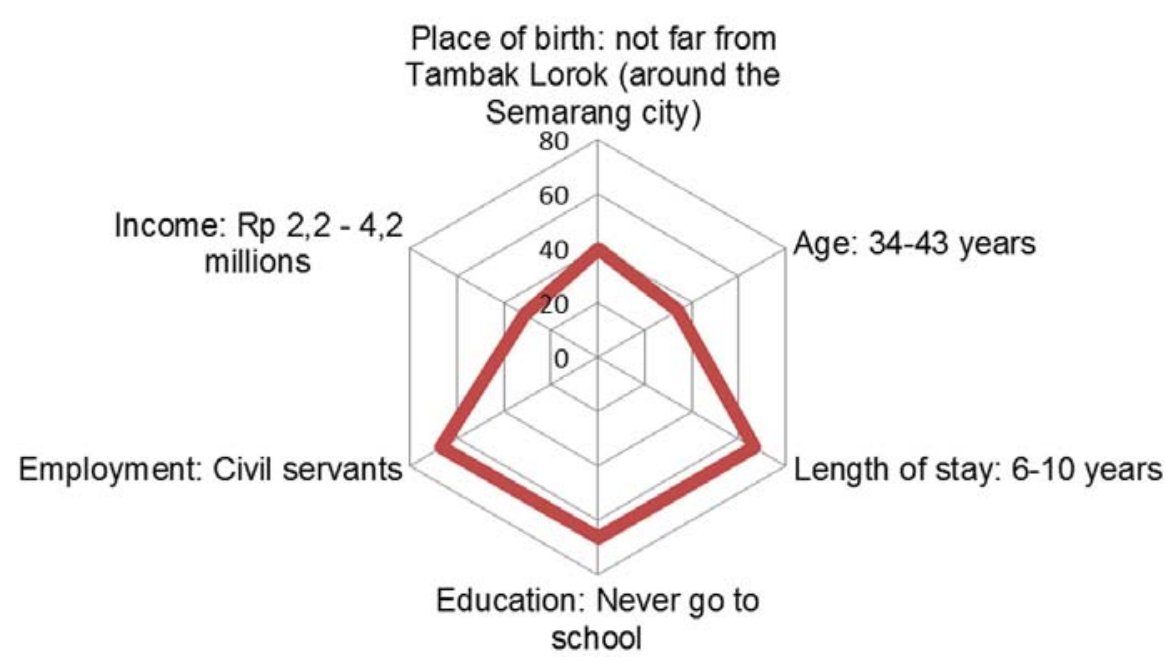

Figure 6. Characteristics of Residents who are uncertain whether staying or moving.

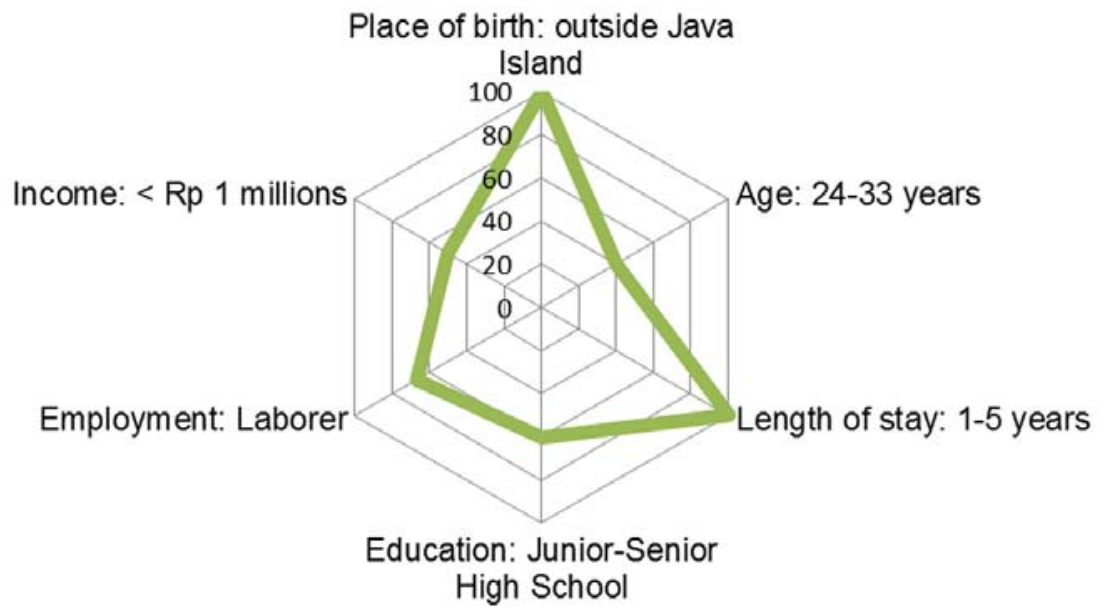

Figure 7. Characteristics of residents who do not want to stay.

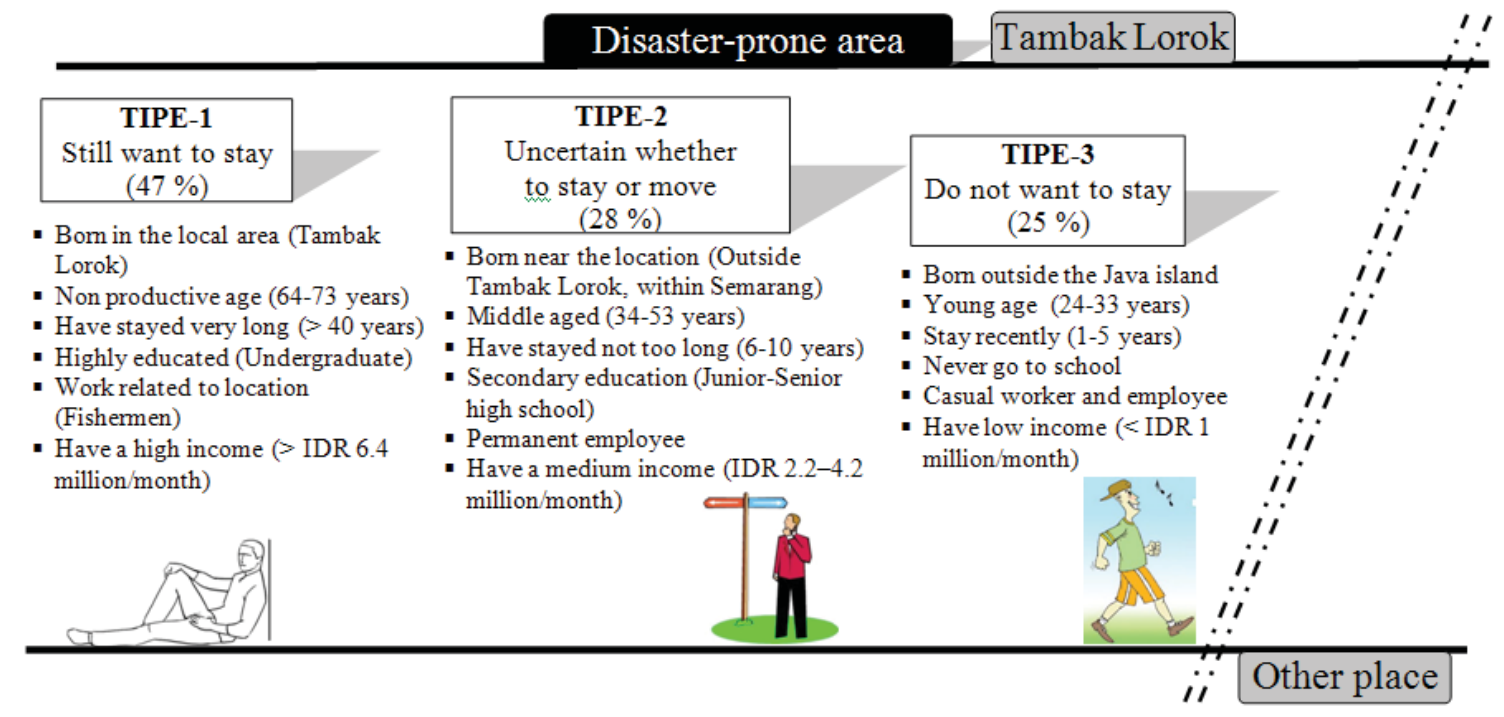

Figure 8. Typology of residents living in disaster-prone area based on their staying intention. 


\subsection{Typology of Residents Living in Disaster-prone Areas}

Typology of residents living in disasterprone areas is categorized by their staying intention. Staying intention in Tambak Lorok is presented in Figure 4. It shows that the number of respondents who still want to stay in Kampung Tambak Lorok are greater $(47 \%)$ than respondents who do not want to stay $(25 \%)$. Meanwhile, the number of respondents that are uncertain between to stay or to move $(28 \%)$ is a little bit larger than respondents who do not want to stay.

Based on their staying intention, the type of residents living in climate change-related disaster-prone areas in Tambak Lorok can be grouped into 3 types, namely: Type 1, those who are still want to stay; Type-2, those who are uncertain whether staying or moving; and Type-3, those who do not want to stay. Afterwards, staying intention data (Figure 4) is crossed with the respondent characteristic data (Figure 2) to explore this typology. The results are then used to describe the characteristics of each type of residents living in the disasterprone areas as follows.

\subsubsection{Type 1: Residents who still Want to Stay (Positive Response)}

Characteristics of residents who still want to stay can be seen in Figure 5 below. It shows that the prominent characteristics of respondents who still want to stay in Tambak Lorok are those whose income is far above UMK Semarang (>IDR 6.4 million). While other characters are born in Tambak Lorok, the eldest ones (64 - 73 years old), have lived long time in Tambak Lorok (41 - 70 years), highly educated (undergraduate), and worked as fishermen.

\subsubsection{Type 2: Type 2: Residents Who Uncertain Whether Staying or Moving (Neutral Response)}

The characteristics of residents who are uncertain of whether staying or moving are presented on the Figure 6. It shows that the prominent characteristics of respondents who answered they are uncertain of whether to stay in Tambak Lorok or to move are those whose employment is civil servants, those who have recently lived in Tambak Lorok (6 - 10 years), and those with the lowest education (never went to school). Other characteristics are those who are born not far from Tambak Lorok (around the Semarang city), whose age is middle aged (34 - 43 years), and whose income is slightly above UMK of Semarang (IDR 2.2 4.2 million).

\subsubsection{Type 3: Residents who Do Not Want to Stay (Negative Response)}

Characteristics of residents who do not want to stay in Tambak Lorok can be seen in Figure 7. It shows that the prominent characteristics of respondents who do not want to stay in Tambak Lorok are those born outside Java Island and those who are just recently lived in Tambak Lorok (1-5 years). Other characteristics are the youngest (24 - 33 years old), have secondary education (junior and senior high school), work as labourers, and have the lowest income and far below UMK of Semarang (less than IDR 1 million).

\subsection{Discussion}

The results of this study indicate a case where people living in disaster-prone areas are likely to have a desire to stay in the area. Residents of Kampung Tambak Lorok decided to keep staying in this area. Although the area face the increasing of tidal inundation affected by climate change in the form of rising sea levels and exacerbated by land subsidence. This fact indicates that living in an environment with hazard-prone conditions is not a strong enough factor to push residents to migrate. This is in line with the results of research conducted in Ghana by Abu et al. (2014) which concluded that people who are living even in areas with perceived environmental stress; climate-related events may not be the primary motivation for migration intentions.

In addition, this result is also in accordance with fourth Ravenstein law of migration which states that there is a difference between urban and rural residents in migration intentions. Urban populations tend to migrate less than rural populations. This is because many of the 
urban population's needs are available in the urban area itself (Ravenstein, 1885). In addition, Kampung Tambak Lorok is located in the rural urban fringe of Semarang City, one of the largest cities in Java Island. The area is experiencing urbanization where the flow of in-migration is greater than out-migration because the area has become the destination of migrants from the surrounding villages. It is as mentioned by Firman et al. (2007) that urbanization in Indonesia is still characterized by a heavy concentration of the urban population in a few large cities. The population on the fringes of large cities is growing rapidly, while the inner cities' population is increasing at a very low rate. The research area located close to the Tanjung Emas industrial area and directly adjacent to Yos Sudarso artery road which is the main transportation route and economy in Java Island. This makes Tambak Lorok has a well-equipped urban infrastructure with good accessibility. The completeness of the urban facilities makes its residents have less migration interest as mentioned in the fourth Ravenstein law of migration.

Furthermore, residents living in this disaster-prone area are grouped into three types based on their staying intention, namely: Type-1 residents who want to stay, i.e. residents who are currently living in Tambak Lorok and declared they want to steadily stay at Tambak Lorok. This type is the majority group in the research area. Type 2 is residents who have not yet decided, i.e. residents who are uncertain whether wanting to stay or move. While the Type 3 is residents who do not want to stay, i.e. residents who are currently living in Tambak Lorok but still have intention of moving to another place. This type is the minority group in Tambak Lorok. The characteristics of each of these typologies can be summarized in Figure 8. By this figure, this study not only describes the typology of people living in hazard-prone area based on their staying intention, but also explains the varying characteristics of people of each typology based on six aspects including place of origin, age, length of stay, education level, employment, and income.
Place of birth, this study shows that the place of origin (place of birth) has a negative relationship with staying intention. This means that the farther the distance of place of origin from the current area of residence, the lower the intention to stay. It can be seen that based on their place of origin, Type-1 (want to stay) are those who were born in Tambak Lorok, while Type-2 (uncertain) are those who were born outside Tambak Lorok but still within the city of Semarang, while the Type-3 (do not want to stay) are those coming from more distant places such as outside the Java Island. This can be described using a theory from Lee (1996) that there are four factors for every decision to migrate including (1) positive and negative factors associated with the place of origin, (2) positive and negative factors associated with the place of destination, (3) intervening obstacles, and (4) personal factors. A person during his lifetime has grown up and received an education in their place of origin in which they experience their youth and recognize the environment very well, therefore he tends to overestimate the positive things and suppress the negative things associated with the place of origin. Hence the place of birth can affect a person's behaviour related to migration. This explains why people born in disaster-prone areas such as Tambak Lorok have a higher staying intention than people born outside the Kampung. This is because the people who were born and grew up in Tambak Lorok have a positive valuation on the condition of Tambak Lorok and put aside the negative factors associated with the Kampung, including the threat of disaster.

Age, the typology of residents living in disaster-prone area also illustrates that age has a positive relationship with the staying intention in disaster-prone areas. This means that the older the residents are, the higher their staying intention in disaster-prone areas. The relationship between staying intention and age can be seen from the age characteristics of each typology. Type-1 (want to stay) are characterized by elderly residents $(>64$ years), Type-2 (uncertain) are characterized 
by middle-aged (34-53 years), while Type3 (do not want to stay) are characterized by younger residents (24-33 years). It also means that non-productive age groups tend to want to stay while productive age groups tend to not wanting to stay. These results are in line with reports from IOM (2015) that migrants are typically between the ages of 16 and 40, suggesting that the age of migrants tends to be dominated by productive age groups. In addition, Kelly (2010) also reported that in many countries migration is seen as a challenge for young people. The evidence found in this study area also shows that those who do not want to stay (want to move) from disasterprone areas are those in productive age group.

The lengths of stay, the typology shows a positive relationship between the lengths of stay in Tambak Lorok with the staying intention. Type-1 are residents who have stayed very long in Tambak Lorok ( $>40$ years), Type- 2 are residents who has lived not too long (6-10 years), while Type- 3 are recent residents ( $<5$ years) at Tambak Lorok. This means that the longer the respondent lives in Tambak Lorok, the stronger their staying intention. This fact is quite worrisome. If the residents who stay longer do not want to move, then this will cause problems in the long term. It is known that slowly but sure the Tambak Lorok area is getting drowned because it is threatened by sea level rise and land subsidence. The dangers and threats of tidal inundation are getting stronger as time passes, but residents who have stay longer do not even want to move. This is of course alarming for the safety of the people who have lived very long there.

Education, one of the highlights in the finding is the correlation between staying intention and education level. The results showed that the higher the level of education, the higher the staying intention in disasterprone areas. The education levels of population in Type- 1 are those with the highest education (undergraduate), while Type- 3 is those with the lowest education (never go to school). The case in Tambak Lorok is in contrast to the results of some previous research which stated that one's educational level does not affect one's staying intention. One of them is the study of Vakhitova \& Coupé (2014) in Ukraine which concluded that there is no statistically significant impact between education and migration intention. Gevrek (2016) also reported similarly from his research in Turkey that the correlation between education and migration may only reflect that these two variables are interrelated, but the actual contribution of education to migration behaviour is zero. The above studies contradict the results of this study which indicates that the level of education has a correlation with staying intention.

The results of this study provide a new fact that higher education have a stronger staying intention in disaster-prone areas such as Tambak Lorok. It is because the highly educated people can obtain sufficient jobs and income to be able to overcome the economic challenges as a consequence of the physical condition of the area, i.e. rising their building to minimise the consequence of tidal inundation. On the contrary, low-educated residents generally cannot afford high-income jobs (usually they work as casual labourers) so they are unable to do such mitigation effort. Moreover, they are also unable to rebuild their damaged-home due to the tidal inundation, therefore, it interferes with their lives. This is a clear factor that encourages people to leave Tambak Lorok. Thus, the level of education is a factor affecting staying intention, although this is not the only factor because it is related to employment and income. From this, we will then discuss the relationship between the desire to live with employment and income.

Employments, the difference in employments affects staying intention. Type1 is those who work as fishermen. This is understandable because Tambak Lorok is close to the sea while the livelihood of fishermen is bound by the sea. It makes the people working as fisherman have a higher staying intention in Tambak Lorok compared to the residents working in other sectors. Type-2 is those who already have status as permanent employees in government agencies (PNS). Though they have established jobs, but they have nothing to do with the sea so they can just move to 
another area if they want to. So they feel uncertain whether to stay in Tambak Lorok and affected by periodic inundation, or move to another area that is not threatened by tidal inundation. Whilst in terms of employment, Type-3 residents work as casual workers and contract employees. Both have an uncertain status because at any time their work may be terminated from their employer or company. Their economy is not strong enough if they have to survive in Tambak Lorok and repair their buildings regularly. In addition, their work is also not directly related to the sea as well as fishermen. These are the factors that make them feel unsure of staying in Tambak Lorok so they are more likely to migrate. As the study of McLeman \& Smit (2006) found, in terms of climate degradation related to climate change, labourers are more likely to migrate than others. This suggests that these types of employments can actually encourage migration.

The typology of residents who do not move from disaster-prone areas when viewed from their income level indicate that there is a difference in staying intention between income groups. High-income residents have a higher staying intention in Tambak Lorok, while lower-income residents feel unsure and do not want to continue to live in Tambak Lorok. This is shown by Type- 1 which is a very high income population above the Semarang City minimum wage, whereas Type- 2 is those whose income equals the minimum wage, and Type- 3 is those whose earnings are even smaller and well below the minimum wage. This situation happens because it is expensive to survive in Tambak Lorok. The residents must have sufficient funds to raise the height of their house to ensure not to be drowned by tidal inundation which increases from year to year. Increasing the height of the house requires a lot of funds, the average cost ranges between IDR 20-30 million (just to raise the bottom of the house), but if they consider renovating the whole house then the cost will be much more expensive, it can even reach hundreds of millions of rupiah. Thus, those who are able to finance house renovations to be safe from tidal inundation are only high-income residents. Meanwhile, low-income residents do not have sufficient funds to finance their house renovation in the future. Therefore, it makes sense that low-income residents tend do not want to stay, while people with excessive income who can afford periodical home renovations tend to want to stay. Warner et al. (2010) states that income is closely related to the extent to which a household can be encouraged to migrate. Several studies has confirmed this linkage, including this study which shows that income is closely related to staying intention, where low-income residents do not want to stay/want to migrate, whereas high-income residents want to stay in the area.

To summarize, this study presents empirical information that staying intention is a key factor of staying decision in disaster-prone areas. The migration intention brings results to migration (moving) behaviour. On the other side, the staying intention brings result to staying behaviour. As stated by De Jong \& Gardner (1981) that the concept of decision making is used in its most general form to refer to the formation of an intention or disposition that result a migration behaviour. This study shows evidence that in disaster-prone areas; residents who have staying intention are more numerous than those with migration intention. This indicates that residents living in disaster-prone areas have a greater staying potential than moving potential. The fact explains why in disaster-prone areas there are number of residents who do not want to move to safer areas. This typology can be applied to understand immobility due to disaster in various places of Indonesia. Many places in Indonesia where the area is threatened by the disaster but the residents are reluctant to move. As in the slope of Mount Merapi, though threatened by the eruption of Merapi that takes place every $4-5$ years periodically but the residents still does not move / migrate from the area. Sontosudarmo (1996) showed that more than 90 percent of the population expressed pleasure to live on the slopes of Merapi and 
did not want to move. As also happened to the people affected by Lapindo mudflow in Sidoarjo that occurred since 2006. The mudflow has not shown any signs of stopping, but the residents are still living around the disasterprone areas (Sukamto, 2016).

Therefore, the understanding of the typology of residents living in disaster-prone areas is important for policy makers. Relocation policies for population from disaster-prone areas often get resistance from residents targeted to be relocated. One similar case is the one described by Napsiah et al. (2016) regarding the people who live in Pungukrejo village which is prone to Mount Merapi eruption.. They refuse to be relocated because the rationality of residents is different from the rationality of government. The government said that Pungukrejo Village is categorized as a disaster-prone area so the residents have to be relocated. On the contrary, for certain groups of the resident, they understand that disaster is something dangerous but an attempt to leave their place is not something they have to do because they have an attachment to Merapi as a place of origin, where they gain a sense of comfort and safety. This is in line with the result of this study that the place of origin is an important aspect associated with staying intention. People originated from or born in disaster-prone areas tend to have a higher staying intention than residents originated from outside the area. Accordingly, before determining policies related to the population living in disaster-prone areas, the government should pay attention to differences in residents' characteristics and distinct intention to stay. There are three types of residents who stay in disaster-prone area. Each type has different characteristics according to their place of origin, age, length of stay, education level, employment, and income. Regarding policy to relocate residents or redevelop the disasterprone areas, government should consider all three types of residents who live in that area. Particular attention should be given to the population of type 1 because they have higher intention to stay compared to other types.
This makes them have a tendency to reject the relocation policy. Therefore, the understanding of type 1 population's characteristics is central if the government choose relocation rather than redevelopment policy.

Hence, there is an implication for policy which emerges from this study of immobile residents' typology. It is certainly imperative to use evidence-based policy making. Head (2010) stated that the important elements of an evidence-based approach are good data, analytical skills, and political support to use scientific information. Motala (2014) cited that government must produce policies that really deal with problem, that are forward-looking and shaped by evidence, rather than giving response to short-term pressures that only tackle causes and not symptoms. Thus, in case of immobile population in disaster threatened area, the synergy between the policy makers and the researchers should be strengthened. Policy makers whose work are related to people living in disaster-prone areas should be encouraged to use data and evidence from field studies to increase their understanding on policy subjects (the residents). Understanding the typology of residents staying in the disaster-prone areas could improve the efficiency and effectiveness of policy options and possible alternatives. If this is applied, the selected policy can be expected to be suitable with the population as the subject of the policy. As a result, the policy can run effectively and most importantly with no more resistance from the residents staying in disaster-prone areas.

\section{Conclusion}

This research contributes some evidence to the debate of migration theory, especially at the micro level (individual). In particular, this study provides empirical evidence that staying intention is a key element in the 'black box' of staying decision in disaster-prone areas. This study found that residents living in disasterprone areas tend to have strong potential to stay in disaster-prone areas, although the staying intention level varies according to place of birth, age, length of stay, education, 
employment, and income. Variation of staying intention levels based on the types of residents living in disaster-prone areas can be used as an explanation of disaster-related populations' immobility.

\section{Acknowledgements}

We would like to acknowledge the Indonesia Endowment Fund for Education (LPDP) Ministry of Finance of the Republic of Indonesia for funding support.

\section{References}

Abidin, H. Z., Andreas, H., Gumilar, I., Sidiq, T. P., Gamal, M., \& Murdohardono, D. (2010). Studying Land Subsidence in Semarang (Indonesia) using Geodetic Methods. In FIG Congress. Facing the Challenges - Building the Capacity Sydney, Australia, 11-16 April 2010 (pp. $1-15)$

Abu, M., Codjoe, S. N. A., \& Sward, J. (2014). Climate change and internal migration intentions in the forest-savannah transition zone of Ghana. Population and Environment, 35(4), 341-364. https://doi.org/10.1007/s11111-013-0191-y

Arief, L. N., Purnama, B. S., \& Aditya, T. (2012). Pemetaan Risiko Bencana Banjir Rob. The 1st Conference on Geospatial Information Science and Engineering, 1-12.

Bardsley, D. K., \& Hugo, G. J. (2010). Migration and climate change: examining thresholds of change to guide effective adaptation decision-making. Population and Environment, 32(2-3), 238-262. https:// doi.org/10.1007/s11111-010-0126-9

De Groot, C., Mulder, C. H., Das, M., \& Manting, D. (2011). Life events and the gap between intention to move and actual mobility. Environment and Planning A, 43(1), 48-66. https:/ / doi.org/10.1068/a4318

De Jong, G. F., Richter, K., \& Isarabhakdi, P. (1996). Gender, values, and intentions to move in rural Thailand. The International Migration Review, 30(3), 748-770. https://doi. org/10.2307/2547635

De Jong, G. F., Root, B. D., Gardner, R. W., Fawcett, J. T., Gardner, R. W., Fawcett, J. T., \& Abad, R. G. (1985). Migration Intentions and Behavior: Decision Making in a Rural Philippine Province. Population and Environment, 8(1), 41-62.

De Jong, G., \& Gardner, R. (1981). Migration Decision Making. Multidisciplinary Approaches to Microlevel Studies in Developed and Developing Countries. Pergamon Press. Retrieved from https://www.sciencedirect.com/science/book/9780080263052

Firman, T., Kombaitan, B., \& Pradono, P. (2007). The Dynamics of Indonesia's Urbanisation, 1980-2006. Urban Policy and Research, 25(4), 433-454. https://doi.org/DOI: $10.1080 / 08111140701540752$

Gevrek, Z. E. (2016). Education and emigration intentions : Evidence from a natural experiment in Turkey. In JEL (pp. 1-36). Retrieved from https://editorialexpress.com/cgi-bin/ conference/download.cgi?db_name=EEAESEM2017\&paper_id $=150$

Head, B. (2010). Evidence-based policy : principles and requirements. In Strenghtening evidencebased policy in the Australian federation - Volume 1: Proceedings. (Vol. 1, pp. 13-26). Canberra: Productivity Commission. https:/ / doi.org/10.1332/1744264052703186

Hugo, G. (2008). Migration, Development and Environment. Switzerland. Retrieved from http:// publications.iom.int/system/files/pdf/mrs_35.pdf

IOM. (2015). World Migration Report 2015 Migrants and Cities: New Partnerships to Manage Mobility. Retrieved from www.iom.int

Kelly, A. (2010). Leaving Home: Voices of Children on the Move, Global Movement for Children. Retrieved from https://resourcecentre.savethechildren.net/sites/default/files/documents/4914. pdf 
King, R. (2012). Theories and typologies of migration: An overview and a primer. Willy Brandt Series of Working Papers in International Migration and Ethnic Relations (Vol. 3/12). Sweden. https:// doi.org/10.4054/DemRes.2014.30.47

Lee, E. S. (1996). A Theory of Migration. Demography, 3(1), 47-57.

Lu, M. (1998). Analyzing Migration Decisionmaking: Relationships between Residential Satisfaction, Mobility Intentions, and Moving Behavior. Environment and Planning A, 30(8), 1473-1495. https:// doi.org/10.1068/a301473

Marfai, M. A., \& King, L. (2008). Coastal flood management in Semarang, Indonesia. Environmental Geology, 55(7), 1507-1518. https:// doi.org/10.1007/s00254-007-1101-3

Marfai, M. A., King, L., Sartohadi, J., Sudrajat, S., Budiani, S. R., \& Yulianto, F. (2008). The impact of tidal flooding on a coastal community in Semarang, Indonesia. Environmentalist, 28(3), 237-248. https:// doi.org/10.1007/s10669-007-9134-4

Massey, D. S. (1999). Social Structure, Household Strategies, and the Cumulative Causation of Migration. Population Index, 56(1), 3-26.

McLeman, R., \& Smit, B. (2006). Migration as an adaptation to climate change. Climatic Change, 76(1-2), 31-53. https://doi.org/10.1007/s10584-005-9000-7

Monograph of Kelurahan Tanjung Mas. (2016). Unpublished manuscript.

Motala, E. (2014). A Note on Evidence-based policy-making. The Research Colloquium on PostSchool Education and Training. The Department of Higher Education and Training, South Africa. Retrieved from http://www.lmip.org.za/sites/default/files/documentfiles// Evidence based policy-making 8 Oct 2014.pdf

Napsiah, Budhi, G., Abdoellah, O. S., \& Munandar, S. (2016). Value Rationality of People Living on The Slope of Merapi in Yogyakarta. Analisa Journal of Social Science and Religion, 1(1), 105-120. https://doi.org/http://dx.doi.org/10.18784/analisa.v1i1.20

Ravenstein, E. G. (1885). The Laws of Migration. Journal of the Statistical Society of London, 48(2), 167-235.

Ryan, T. P. (2013). Sample Size Determination and Power. (D. J. Balding, N. A. C. Cressie, G. M. Fitzmaurice, H. Goldstein, I. M. Johnstone, G. Molenberghs, ... S. Weisberg, Eds.). New Jersey: John Wiley \& Sons. https://doi.org/10.1002/9781118439241

Sontosudarmo, A. (1996). Persepsi Pengungsi Merapi dalam Transmigrasi. Majalah Geografi Indonesia, 10(18), 37-57.

Suhelmi, I. R., Fahrudin, A., \& Triwibowo, F. H. (2014). Potential Economic Losses Due to Tidal Inundation and Flood at Semarang City. Forum Geografi, 28(2). https://doi.org/10.23917/ forgeo.v28i2.428

Sukamto. (2016). Mengenang Sepuluh Tahun Bencana Industri Lumpur Lapindo dan Tindakan Kolektif para Korban. Jurnal Teori Dan Pembelajaran IPS, 1(1), 52-64. Retrieved from http:/ / journal2.um.ac.id/index.php/jtppips/article/viewFile/228/185

Vakhitova, H., \& Coupé, T. (2014). The Relationship between Education and Migration. The Direct Impact of a Person's Education on Migration Education and Decision to Migrate. Retrieved from http://freepolicybriefs.org/wp-content/uploads/2014/06/freepolicybriefs_kei_june24. pdf

Warner, K., Hamza, M., Oliver-Smith, A., Renaud, F., \& Julca, A. (2010). Climate change, environmental degradation and migration. Natural Hazards, 55(3), 689-715. https://doi. org/10.1007/s11069-009-9419-7 